Legal

\title{
Parenthood should not be regarded as a right
}

M Maclean

In September 2004 the BBC broadcast a debate in the Straw Poll series about whether parenthood should be regarded as a right. The motion was carried by a large majority both among the audience present at the recording, and among listeners who were invited to telephone in with their votes, and views at a subsequent feedback programme. The arguments are presented here, in order to stimulate debate among readers.

$\mathrm{P}$ arenthood is a status, which carries with it responsibilities and obligations. These fall not only on the individual parents, but on society as a whole through the need to pay for health care, schooling, and other services. Parenthood is also a source of great joy. For many men and women this may be their first experience of unconditional love. The anguish of those who have difficulty in becoming parents must not be underestimated.

Nevertheless, in law in the UK in 2004 there is no right to parenthood, nor in my view should there be. The language of rights does not sit easily with the language of parenthood.

Our Children Act of 1989, which is admired and emulated in many other jurisdictions, which brings together legislation concerning the welfare of children, does not use the language of rights but of responsibilities towards children. In any dispute arising concerning children where the courts are called in to make a decision, the guiding principle for the judge is the best interest of the child and not the rights of adults.

The European Convention on Human Rights, now enshrined in our statute law in the Human Rights Act, 1998 does indeed under Article 12 protect the right to marry and found a family. But does this include the right to produce a child? In the few cases heard in this country Article 12 has not been held to include the right to infertility treatment. In the Prisoner case, ${ }^{1}$ a man serving a prison sentence for murder who had married a prison warder aged 25, asked for the right to deposit sperm as he feared that by the time he was released in six years' time she would be too old to have a child. The Court of Appeal turned him down, arguing that his problem was the natural consequence of being in prison and there should be no special treatment. Article 12 does not confer an absolute right to be enabled to procreate, though in other circumstances, for example if a male partner were about to undergo chemotherapy treatment which would render him infertile, Article 12 might require the prison service to grant him permission to store sperm for future use.

There is not only no legal right to become a parent; there is not even a right to medical treatment. This lack may be open to criticism. But it may be helpful to consider briefly how new we are to talking about rights in this country. Our rights based legislation has traditionally been concerned with negative rights - the right not to be burgled or not to be physically harmed or threatened. Historically we have not been endowed with positive rightsthat is, the right to something. This is because it is difficult to establish a right to anything which has to be paid for. A right to a certain standard of living or of health care will inevitably have resource implications for the public purse. The European Convention on Human Rights arose in response to the fascist government excesses of the Second World War, and was designed to control government intervention in the life of the individual. It was never designed to provide positive access to resources in the way which access to fertility treatment would require.

The question of providing fertility treatment has been referred to National Institute for Clinical Excellence (NICE), whose purpose is to ensure that funding decisions are made fairly and consistently across the NHS. They recommended that each infertile couple should have three cycles of treatment at public expense. The government has agreed to provide a single cycle. With the current rate of success of
$20 \%$ this is hardly a guaranteed right to parenthood

The legal position is clear. There is no right to infertility treatment or to parenthood.

But should there be such a right? Let me return to why I am uncomfortable with the language of rights in the context of parenthood.

A right to parenthood in my view is unhelpful because it focuses on the rights of adults rather than the needs of children. If we look ahead in the life of the child this kind of rights based approach has become associated with the kinds of arguments which have been raging over the rights of fathers to equal rights to their child's time after separation or divorce. A concentration on parental rights, in my view, leads us towards the danger of regarding a child as a piece of property to be divided, towards the excesses of the extreme fathers groups, and away from the sanity of the Children Act 1989 with its focus on the child.

I want to see concentration not on parental rights but on parental responsibilities, not on the right to have a child, but on the needs and welfare of all children. The road to the right to parenthood is a slippery slope. It is neither desirable nor enforceable. Arguments about resource allocation within health care, pitching the needs of infertile couples against treatment for heart disease or cancer would be inappropriate and unhelpful. We have to remember that access to fertility treatment depends on resources, not on law.

On the other hand, in my view it is equally undesirable for the law to interfere in the reproductive autonomy of the individual and be used to prevent fertility. There are aspects of the legal regulation of access to fertility treatment which do merit attention. In particular, there is an assumption in the Human Fertilisation and Embryology Act 1990 that no one shall receive assistance with conception unless account is taken of the welfare of any child who might be born as a result of treatment, including the need of that child for a father. This clause has limited the availability of treatment to single or lesbian women, and goes to the heart of what Professor Emily Jackson describes as reproductive autonomy. $^{2}$

The role of law is to provide a framework within which disputes arising between individuals or between individuals and the state about access to fertility procedures can be resolved, while both respecting individual autonomy and safeguarding the welfare of children but not guaranteeing parenthood. 


\section{ACKNOWLEDGEMENTS}

This article is based on contributions to Straw Poll, BBC4, September 2004, TestBed Productions.

Arch Dis Child 2005;90:782-783.

doi: $10.1136 /$ adc. 2004.064493
Correspondence to: Dr M Maclean, Oxford Centre for Family Law and Policy, Department of Social Policy, 32 Wellington Square, Oxford OX2 1ER, UK; mavis.maclean@applied-socialstudies.oxford.ac.uk

Competing interests: none declared

\section{REFERENCES}

$1 \mathrm{R} v$ Secretary of State Home Office ex parte Mellor, [2001] EWCA Civ 472, [2001] 3 WLR 533.

2 Jackson E. Conception and the Welfare Principle. Modern Law Review 2002;65:196-203.

\section{IMAGES IN PAEDIATRICS}

\section{"Sour skin" in Darfur, Sudan}

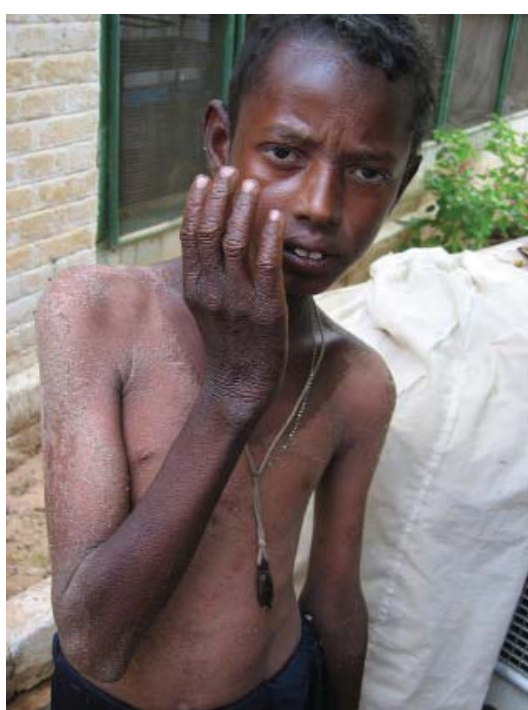

Consent was obtained for publication of this figure

\begin{abstract}
13 year old boy presented to a field hospital in West Darfur, Sudan, with a mildly pruritic rash for six months involving the face, upper chest, and distal extremities. The facial eruption was characterised by hyperpigmentation and areas of peeling resembling sunburn. Lesions of the forearms, hands, and feet were strikingly symmetrical, hyperpigmented, thickened, and scaly. There was a clear zone of demarcation between affected and normal skin. No gastrointestinal or neurological disturbances were present and physical examination was otherwise unremarkable. The patient's diet consisted solely of locally prepared dura, or cooked millet, without milk or other sources of animal protein. Given the history and the particular characteristics of the dermatitis-photosensitivity, "stocking glove" forearm distribution, and well defined involvement of the upper chest (often referred to as "Casal's necklace") - a presumptive diagnosis of pellagra secondary to dietary niacin deficiency was established. ' Of note, the word "pellagra" derives from the Italian, "pelle agra", meaning "sour (or rough) skin". Oral replacement with $90 \mathrm{mg}$ of nicotinic acid once daily was initiated. Significant improvement was noted when the patient returned for follow up at approximately
\end{abstract} one month.

J M Spector

Harvard School of Public Health, 677 Huntington Avenue, Boston, MA, USA; jspector@hsph.harvard.edu

\section{REFERENCE}

1 Karthikeyan K, Thappa DM. Pellagra and skin. Int J Dermatol 2002;41:476-81. 